\title{
Substance abuse and pain in a cohort of college students
}

\author{
Elena Ferrer ${ }^{1}$, Ray Marks ${ }^{1,2^{*}}$, Elizabeth Midlarsky ${ }^{3}$ and Aida Hutz-Midgett ${ }^{4}$ \\ *Correspondence: rm226@columbia.edu

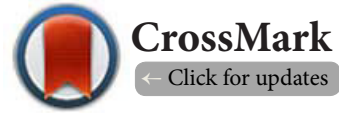 \\ 'Department of Health and Behavior Studies, Teachers College Columbia University, New York, USA. \\ ${ }^{2}$ Department of Health and Physical Education, School of Health and Behavioral Sciences, York College, \\ City University of New York,USA. \\ ${ }^{3}$ Department of Counseling and Clinical Psychology, Teachers College Columbia University, New York, USA. \\ ${ }^{4}$ Department of Counselor Education, Boise State University, USA.
}

\begin{abstract}
Objectives: Substance abuse is widespread among college students. This study strove to: (1) Examine the prevalence of substance abuse among college students; (2) The prevalence of pain among this sample; (3) The relationship between substance abuse and pain among this cohort.

Participants: Participants were 244 undergraduate students from a large public Midwestern College. Methods: Subjects completed three surveys: A Demographic Survey, a validated Drug Abuse Screening tool; and Pain Questionnaire.

Results: (1) The prevalence of substance abuse was 11.5\%; (2) The prevalence of pain was 9.7\%; (3) Pain was strongly and positively associated with drug use $(<0.01)$; (4) This association was stronger for women than men, and for Seniors, rather than Freshman $(<0.05)$.

Conclusions: In general, the finding that pain and drug use were strongly and positively linked among this cohort of college students, but varied with gender and years in college, may be useful for designing future tailored prevention programs.
\end{abstract}

Keywords: College students, drug abuse, pain, prevention

\section{Introduction}

Ample research suggests many people today suffer pain without relief, including college students [1]. It is also well established that people in pain may abuse drugs [2-4]. In 2010, approximately 5.1 million people abused pain medication (2.0 percent of the US population), and 7.0 million people abused other types of drugs to relieve pain (2.7 percent of the US population) [5]. It is unclear, however, if college students who may experience pain and are known to be very apt to consume drugs are taking these in association with pain. It is also unclear if pain and drugs use are related, or whether other factors mediate or moderate this relationship in the context of college students.

For decades researchers have had the important task of tracking the consumption of toxic substances among college students [6-8]. The study of pain overtime since 2007 has concluded that there is an increasing prevalence rate of nonmedical use of prescription drugs in college students $[9,10]$. For example, from 1999 to 2006, the number of deaths due to fatal poisonings involving opioid analgesics increased more than 3 times [11]. Previous studies on substance abuse have, generally, reported related prevalence data $[12,13]$, social context [13,15], medical aspects [16,17], biological issues [18], economic expenses [19], and negative outcomes, but none discussed pain. Similarly, previous pain studies, generally explored pain prevalence, medical aspects of pain [20], biology issues [21], economic expenses [22], and negative outcomes, but not specifically drugs and their use or abuse on campuses.

Due to the limited number of studies regarding a possible link between substance abuse and pain in college students, this study attempted to fill this gap by examining the link between pain and substance abuse in a specific cohort of college students.

The specific goals of this exploratory research were to: (1) Examine the prevalence rates of substance abuse among a sample of college students in the US; (2) Assess the prevalence of pain among these college students; (3) Analyze the relationship between substance abuse, and pain among this cohort.

This study investigated the directional hypothesis that 
Ferrer et al. Research Journal of Drug Abuse 2015,

substance use and pain are positively related.

\section{Methods}

\section{Participants and procedures}

The present cross-sectional study used data obtained from a 2010 survey of 244 undergraduate students from a Midwest college in the US conducted between May 14, 2010 and June 15,2010 . The sample included women and men of at least 18 years of age who were surveyed on a single occasion in the classroom setting. IRB approval was obtained from the college and all eligible subjects were required to provide informed consent.

Fliers were posted around a campus that agreed to participate to inform students about the new research and they were asked if they wanted to participate. Furthermore, professors were informed about the study and the future plans for data collection. A skilled collaborator collected data at this Midwest College. Specifically, filling out the surveys took place in private rooms designated for this purpose. Students were seated at certain distance from each other to ensure the privacy of the answers. The participants were not paid. Further, it was ensured the subject's confidentiality of data and all participants were identified by number, not by name. Data was collected anonymously. Data material was stored in a locked cabinet.

After receiving instructions about the nature of the study and its risks by an independent experienced proctor, the participants who all provided informed consent were administered several questionnaires designed to answer the study questions in a systematic manner. The first survey was a demographic one. The second questionnaire was related to substance use and the third to pain: The Drug Abuse Screening Test (DAST-10) [23] and the Short-Form McGill Pain Questionnaire (SF-MPQ) [24].

The Drug Abuse Screening Test (DAST-10) [23] is a brief reliable 10-item self-report scale that measures drug substance use (except alcohol and tobacco) and has been shortened from the DAST-20 scale [25].This measure is scored by allocating 1 point for each question answered, "yes", except for question 3 for which a "no" answer receives 1 point and 0 for a "yes".

The Short-Form McGill Pain Questionnaire (SF-MPQ) [24] is a 15 -item self-report measure. The SF-MPQ is divided in 3 parts. The first section consists of 2 independent factors all rated on a 4-point severity scale, ranging from $0=$ none to $3=$ severe. Descriptors 1-11 represent the sensory dimension of the pain experience and items 12-15 represent the affective dimension. The second section includes a Visual Analog Scale (VAS) [26], which is a $10 \mathrm{~cm}$ horizontal line representing no pain on one end to worst possible pain on the other. The third section evaluates overall present pain intensity experience on a 6-point scale where $(0=$ no pain, $1=$ mild pain, $2=$ discomfort, $3=$ distressing pain, $4=$ horrible pain, $5=$ =xcruciating pain). Three separate MPQ pain scores are then calculated by summing the intensity rank values of the words chosen for the sensory, affective, and composite descriptors. The test- retest reliability of this scale ranges between $r=0.76$ to 0.78 (See Supplementary files).

\section{Data analysis}

After the data was acquired, the dataset was entered onto a computer spreadsheet using PSAW 18.00 (SPSS) [27]. In dealing with the data two procedures were applied, data screening and data analysis. The data screening included an inspection of the descriptive statistics and procedures to establish the accuracy of the data input variables. The first step of the data analysis involved performing a descriptive analysis. The second step involved performing a Chi-square test to detect significant differences between the different levels of each categorical variable (e.g., age, gender, and ethnicity). Also Pearson Product-Moment correlation tests were utilized to examine the strength of the relationship between drugs use and pain among the present cohort. Significance was set at $p<0.05$.

\section{Results}

A total of 155 women and 86 men were studied. The majority was female (63.5\%) and most were non-Hispanic whites (79.5\%). The results showed that $48.8 \%$ were 24 years of age or older with a mean of 20.5 (see Table 1). The lifetime prevalence of substance abuse and pain among college students in this

Table 1. Demographics.

\begin{tabular}{lll}
\hline Variable & N (\%) & Mean (SD) \\
\hline Age & $123(50.2)$ & $20.5(11.5)$ \\
\hline Younger than 24 & $119(48.6)$ & n/a \\
Older than 24 & 2 & -- \\
Missing values & & \\
\hline Gender & $86(35.3)$ & -- \\
\hline Male & $155(63.5)$ & -- \\
Female & 3 & -- \\
Missing values & & \\
\hline Ethnicity & $194(79.5)$ & -- \\
\hline Caucasian & $46(18.8)$ & -- \\
Other (Minority) & 4 & -- \\
Missing values & & \\
\hline College level & $42(17.2)$ & -- \\
\hline Freshman & $35(14.3)$ & -- \\
Sophomore & $51(20.9)$ & -- \\
Junior & $108(44.3)$ & -- \\
Senior & $0(0)$ & -- \\
Graduate & $8(3.3)$ & -- \\
Other & $124(50.6)$ & -- \\
\hline Religion versus no religion & $124(49.2)$ & -- \\
\hline Religion & 0 & -- \\
No religion & & \\
Missing vales & & \\
\hline & & \\
\hline
\end{tabular}


Ferrer et al. Research Journal of Drug Abuse 2015,

study was $11.5 \%$ and $9.7 \%$ respectively (see Tables 2 and 3). Other associations are shown in Tables $\mathbf{4}$ and $\mathbf{5}$ and include significant correlations between pain (MPQ) and substance use (DAST-10).

In terms of an association between the variables of pain and drug use, these were positively correlated at a statistically significant level $(<0.01)$. See Figure 1.

\section{Discussion}

Both substance abuse and pain are prevalent problems in the United States and worldwide. This study explored: (1) The prevalence of drug use in a convenience sample of US college students; (2) The prevalence of pain in this cohort; (3) The relationship between demographic factors, substance abuse, and pain among this cohort, an understudied group.

Table 2. Prevalence of harmful drug use among college students in this study.

\begin{tabular}{|c|c|c|c|c|c|}
\hline Variable & $\begin{array}{l}\text { Total } \\
\text { N (\%) }\end{array}$ & $\begin{array}{l}\text { Not harmful } \\
\text { drug use } \\
\mathrm{N}(\%)\end{array}$ & $\begin{array}{l}\text { Harmful } \\
\text { drug use } \\
\mathrm{N}(\%)\end{array}$ & $\chi^{2}$ & P value \\
\hline DAST-10 & 229 & $204(89.1)$ & $25(11.5)$ & -- & -- \\
\hline \multicolumn{6}{|c|}{ (Drug abuse screening test) } \\
\hline \multicolumn{6}{|l|}{ Age } \\
\hline Younger than 24 & 113 & $98(86.7)$ & $15(13.3)$ & -- & -- \\
\hline Older than 24 & 117 & $107(91.5)$ & $10(8.5)$ & -- & -- \\
\hline Group difference & -- & -- & -- & 1.33 & 0.249 \\
\hline Missing values & $14(5.7 \%)$ & -- & -- & -- & -- \\
\hline \multicolumn{6}{|l|}{ Gender } \\
\hline Male & 81 & $70(86.4)$ & $11(13.6)$ & -- & -- \\
\hline Female & 148 & $134(90.5)$ & $14(9.5)$ & -- & -- \\
\hline Group difference & -- & -- & -- & 0.91 & 0.340 \\
\hline Missing values & $15(6.1 \%)$ & -- & -- & -- & -- \\
\hline \multicolumn{6}{|l|}{ Ethnicity } \\
\hline Caucasian & 186 & $166(89.2)$ & $20(10.8)$ & -- & -- \\
\hline Other (Minority) & 44 & $39(88.6)$ & $5(11.4)$ & -- & -- \\
\hline Group difference & -- & $\mathrm{n} / \mathrm{a}$ & $\mathrm{n} / \mathrm{a}$ & -- & -- \\
\hline Missing values & $14(5.7 \%)$ & -- & -- & -- & -- \\
\hline \multicolumn{6}{|l|}{ College level } \\
\hline Freshman & 39 & $35(89.7)$ & $4(10.3)$ & -- & -- \\
\hline Sophomore & 31 & $27(87.1)$ & $4(12.9)$ & -- & -- \\
\hline Junior & 49 & $43(87.8)$ & $6(12.2)$ & -- & -- \\
\hline Senior & 104 & $93(89.4)$ & $11(10.6)$ & -- & -- \\
\hline Graduate & -- & $\mathrm{n} / \mathrm{a}$ & $\mathrm{n} / \mathrm{a}$ & -- & -- \\
\hline Other & 7 & $7(100.0)$ & $0(0.0)$ & -- & -- \\
\hline $\begin{array}{l}\text { Group difference } \\
\text { (between } \\
\text { Freshman and } \\
\text { senior) }\end{array}$ & -- & $\mathrm{n} / \mathrm{a}$ & $\mathrm{n} / \mathrm{a}$ & -- & -- \\
\hline Missing values & $14(5.7 \%)$ & -- & -- & -- & -- \\
\hline
\end{tabular}

DAST-10/Age ( $\mathrm{N}=230)$; DAST-10/Gender ( $\mathrm{N}=229)$; DAST-10/ Ethnicity ( $\mathrm{N}=230)$; DAST-10/College Level $(\mathrm{N}=230)$; DAST-10/ Religion ( $\mathrm{N}=230)$; DAST-10/Current Living Arrangement $(\mathrm{N}=230)$.
Table 3. Prevalence of pain among college students in this study as measured using SF-MPQ (Short Form McGill) (N=237).

\begin{tabular}{lllll}
\hline Variable & \multicolumn{5}{c}{ Level of pain } \\
\hline & None & Mild & Moderate & Severe \\
& $\mathbf{N}(\%)$ & $\mathbf{N}(\%)$ & $\mathbf{N}(\%)$ & $\mathbf{N}(\%)$ \\
\hline Age & & & & \\
\hline Younger than 24 (N=123) & $86(69.9)$ & $20(16.3)$ & $12(9.7)$ & $5(4.1)$ \\
Older than 24 (N=114) & $80(70.2)$ & $17(14.9)$ & $11(9.6)$ & $6(5.3)$ \\
\hline Gender & & & & \\
\hline Male (N=84) & $61(72.6)$ & $12(14.3)$ & $8(9.5)$ & $3(3.6)$ \\
Female (N=153) & $106(69.3)$ & $25(16.3)$ & $15(9.8)$ & $7(4.6)$ \\
\hline Ethnicity & & & & \\
\hline Caucasian (N=192) & $138(71.9)$ & $28(14.6)$ & $19(9.9)$ & $7(3.6)$ \\
Minority (N=5) & $29(64.4)$ & $8(17.8)$ & $5(11.1)$ & $3(6.7)$ \\
\hline
\end{tabular}

Table 4. Significant correlations between pain (MPQ) total score and substance use (DAST-10) total score.

\begin{tabular}{|c|c|c|c|c|}
\hline Variables & $\begin{array}{l}\text { N (pain) } \\
\text { (MPQ) }\end{array}$ & $\begin{array}{l}\text { N (drug) } \\
\text { (DAST-10) }\end{array}$ & $\mathbf{R}$ & $P$ value \\
\hline $\begin{array}{l}\text { MPQ total score and } \\
\text { substance use (DAST-10) } \\
\text { total score }\end{array}$ & 229 & 230 & 0.287 & 0.003 \\
\hline $\begin{array}{l}\text { MPQ total score and } \\
\text { "abusing more than one drug } \\
\text { at a time" (DAST-10) (2) }\end{array}$ & 229 & 226 & 0.165 & 0.013 \\
\hline $\begin{array}{l}\text { MPQ total score and "guilt } \\
\text { because of drug use" } \\
\text { (DAST-10) (5) }\end{array}$ & 229 & 226 & 0.137 & 0.039 \\
\hline $\begin{array}{l}\text { MPQ total score and "spouse } \\
\text { (or parent) complaining } \\
\text { about your involvement with } \\
\text { drugs" (DAST-10) (6) }\end{array}$ & 229 & 225 & 0.159 & 0.017 \\
\hline $\begin{array}{l}\text { MPQ total score and } \\
\text { "neglecting your family } \\
\text { because of drug use" } \\
(\text { DAST-10) }(7)\end{array}$ & 229 & 226 & 0.162 & 0.015 \\
\hline $\begin{array}{l}\text { MPQ total scores and } \\
\text { "withdrawal symptoms when } \\
\text { you stopped taking drugs" } \\
\text { (DAST-10) (9) }\end{array}$ & 229 & 226 & 0.197 & 0.003 \\
\hline $\begin{array}{l}\text { MPQ total score and } \\
\text { "abusing more than one drug } \\
\text { at a time" (DAST-10) (2) }\end{array}$ & 229 & 226 & 0.165 & 0.013 \\
\hline $\begin{array}{l}\text { MPQ total score and "guilt } \\
\text { because of drug use" } \\
\text { (DAST-10) (5) }\end{array}$ & 229 & 239 & 0.119 & 0.074 \\
\hline $\begin{array}{l}\text { MPQ total score and "spouse } \\
\text { (or parent) complaining } \\
\text { about your involvement with } \\
\text { drugs" (DAST-10) (6) }\end{array}$ & 229 & 238 & 0.159 & 0.017 \\
\hline $\begin{array}{l}\text { MPQ total score and } \\
\text { "neglecting your family } \\
\text { because of drug use" } \\
(\mathrm{DAST}-10)(7)\end{array}$ & 229 & 239 & 0.162 & 0.015 \\
\hline $\begin{array}{l}\text { MPQ total Sscores and } \\
\text { "withdrawal symptoms when } \\
\text { you stopped taking drugs" } \\
\text { (DAST-10) (9) }\end{array}$ & 229 & 239 & 0.197 & 0.003 \\
\hline
\end{tabular}


Ferrer et al. Research Journal of Drug Abuse 2015,

http://www.hoajonline.com/journals/pdf/2057-3111-2-1.pdf

Table 5. Correlation between pain (MPQ) total scores and drug abuse (DAST-10) (Harmful Use of Drugs) regarding age, gender, ethnicity, college level, religion, and present living arrangement.

\begin{tabular}{|c|c|c|c|c|}
\hline Variables & $\begin{array}{l}\text { N (pain) } \\
\text { (MPQ) }\end{array}$ & $\begin{array}{l}\text { N (drug) } \\
\text { (DAST-10) }\end{array}$ & $\mathbf{R}$ & P value \\
\hline \multicolumn{5}{|l|}{ Age } \\
\hline Younger than 24 & 15 & 15 & 0.356 & 0.193 \\
\hline Older than 24 & 9 & 10 & 0.365 & 0.334 \\
\hline \multicolumn{5}{|l|}{ Gender } \\
\hline Male & 10 & 11 & -0.086 & 0.813 \\
\hline Female & 14 & 14 & 0.580 & 0.030 \\
\hline \multicolumn{5}{|l|}{ Ethnicity } \\
\hline Caucasian & 6 & 7 & 0.652 & 0.161 \\
\hline $\begin{array}{l}\text { Other } \\
\text { (Minority) }\end{array}$ & 6 & 6 & -0.453 & 0.367 \\
\hline \multicolumn{5}{|l|}{ College level } \\
\hline Freshman & 3 & 3 & -0.378 & 0.622 \\
\hline Sophomore & 4 & 4 & 0.209 & 0.791 \\
\hline Junior & 6 & 6 & 0.182 & 0.729 \\
\hline Senior & 9 & 10 & 0.671 & 0.048 \\
\hline Graduate & 0 & 0 & -- & -- \\
\hline Other & 0 & 0 & -- & -- \\
\hline \multicolumn{5}{|l|}{ Religion } \\
\hline Having religion & 14 & 15 & 0.274 & 0.344 \\
\hline No religion & 9 & 9 & 0.574 & 0.106 \\
\hline \multicolumn{5}{|c|}{ Present living arrangement } \\
\hline Residence hall & 1 & 1 & -- & -- \\
\hline Off-campus & 15 & 16 & 0.329 & 0.231 \\
\hline With family & 7 & 6 & -0.102 & 0.848 \\
\hline Other & 1 & 1 & -- & -- \\
\hline
\end{tabular}

Note: The sample of the study is $\mathrm{N}=244$. Some cells are too small to calculate.

Based on the three goals of this study, the results in Table 2 showed the following: In relation to goal one, the annual prevalence of substance abuse among college students by employing the measures DAST-10 [23] was $11.5 \%$. This percentage is lower than the $28 \%$ annual prevalence reported in McCabe et al., [28] regarding the medical use of prescription drugs for nonmedical purposes among college students aged 18 to 25. This discrepancy between these results might be due to several facts. One, the difference between reporting drug use or drug abuse. For example, this study specifically explored drug abuse (the harmful excess of consuming drugs) compared to the study of McCabe et al., [28] in which the prevalence of illicit and prescription drugs focused in both the general use (how many students consumed the drugs) or misuse (excessive use of the drugs). Second, the types and combinations of surveys utilized in the studies differed. For example, this present study utilized the DAST-10 versus items from other surveys used by McCabe et al., [28] Third, the number of drug

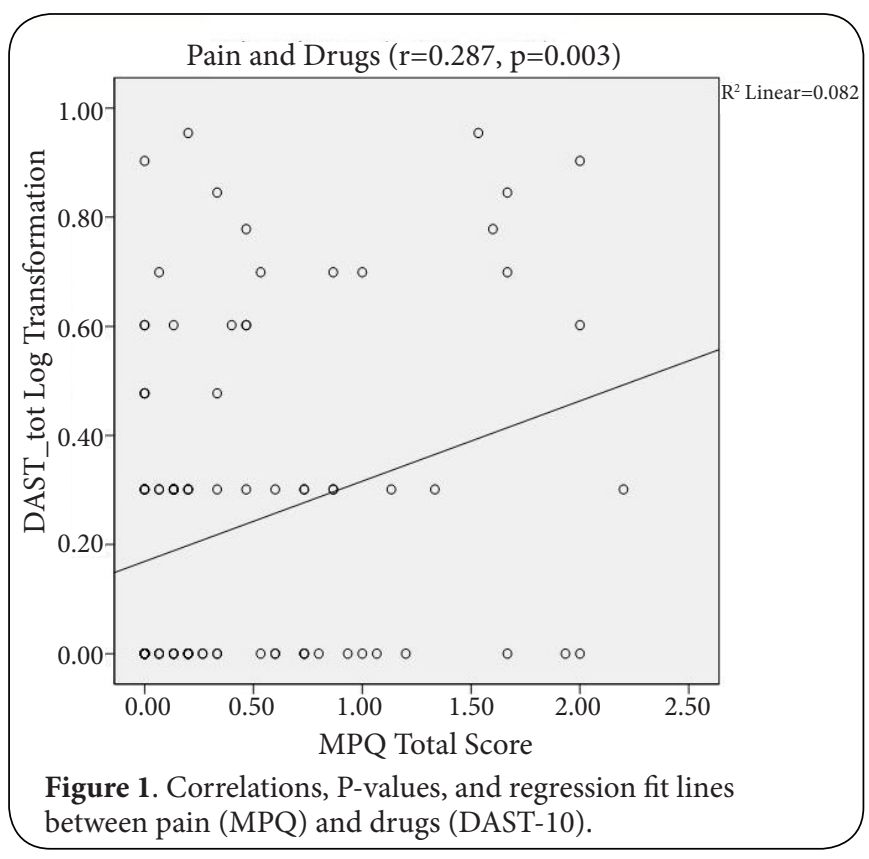

categories and drug related issues differed. Fourth, the type of drugs reported in the results differed. Fifth, the age of the college students was slightly different.

However, the $11.5 \%$ substance abuse rate found in our study takes on special importance when we compare it with the 13\% of arrests for drug use (no alcohol) in the same college where our study was performed. In reference to age and drug use, this study accords with 2002 National data [29]. Our research also provides evidence that among this Midwest cohort of students, those who were younger than 24 years of age had higher rates of usage than the cohorts above this age. This is similar to the National 2002 study findings on drug use and health where college students younger than 25 years of age were found to have the highest non-medical usage rates of potentially addictive harmful prescription drugs in the US [29].

In exploring goal 2 (Table 3 ), this research found the prevalence of pain of $9.7 \%$ among this cohort of students was quite difficult to compare with previous work. One reason for this is that other studies about pain in college students have tended to focus on specific body areas (e.g., head, back, musculoskeletal, menstrual), while this study explored pain in general. Regarding gender, this study found no significant difference in pain levels between males and females. Again, it was difficult to compare the difference in pain levels regarding gender between this study and others due to the type of pain that was taken in consideration. In this sense this study provides a novel previously undocumented contribution to the related literature that can be further explored in the future.

In exploring goal 3 (Figure 1 and Table 4), the present research found that the relationship between the composite pain and drug abuse scores (not including alcohol) was positively correlated at a statistically significant level $(<0.01)$. 
This relationship is similarly difficult to compare with previous studies because most of the earlier research on pain and drug abuse focused on prevalence, and when a relationship between pain and drug abuse was reported, it was usually on alcohol alone. Interestingly, when exploring religion, we found that the relationship between pain and drug use (not including alcohol) was higher among students with no affiliation to a religion $(r=0.574, p>0.05)$ than those who reported affiliation to a religion ( $r=0.274, p>0.05)$.

Regarding age, the relationship between pain and drug use (no alcohol involved) among the two age groups of college students (younger than 24 years and older than 24 years) was positively associated, but not at significant level (Table 5). Although at most US colleges, students start college after high school (18 years old) and graduate in 4 years (22y), 24 was selected as the binary cutoff age in the present study because the demographic survey asked about each specific age beginning at $18(18,19,20,21,22,23,24)$, but after age 24 , the survey asked individuals if they were older than 24 years of age (as opposed to asking for a specific age). The median age was not used in the present analysis for the same reason. The explanation regarding why the mean age in this study is 20.5 years is probably because the study surveyed undergraduate students both in the Associate and Baccalaureate programs and the college confers Associate, Baccalaureate, Masters, and Doctoral degrees, not only undergraduate degrees. In a previous study [30] in which only drug use (not harmful use) was analyzed in this specific association, the relationship observed was an inverse one. In the present case, the results yielded an inverse association when analyzing the relationship between pain and drug use (not including alcohol) among Freshmen students, while the correlation of drug use and pain was statistically significant among Seniors ( $r=0.671$, $p<0.05$ ). These findings suggest that Seniors are at higher risk for consuming addictive drugs than Freshman students. In general, it was found that as years in college increased, the harmful consumption of drugs also increased. This conveys the idea that colleges should probably focus their substance use prevention programs on Junior students.

In reference to living arrangements (Table 5), it was difficult to determine the relationships among these because some cells were too small to generate meaningful results. The association between pain and drug use among college students living with family was an inverse one $(r=-0.102,>0.05)$ (Table 5). This means that it is possible that students may restrain themselves more often when living with family members. Alternately, the finding of a relationship between pain and drug use among college students who live off-campus (see Table 5) suggests that students living off-campus consume drugs in a more harmful manner when they are not supervised either by the college or by the family.

\section{Conclusions}

A reasonable percentage of college students may be abusing harmful drugs due to unrelenting pain or limited pain coping ability. Based on the particular finding that as pain increases drug use increases (at significant level), it is reasonable to imply that individuals at risk for pain should be assessed for possible abuse of toxic substances. Pending further research to tease out the cause effect of the presently observed relationship, it is recommended colleges and universities specifically promote and foster pain screenings among females as well as those students not affiliated with a religion in order to prevent excess drug use due to pain on campus. Furthermore, health services personnel on campuses should possibly do more to both screen for either of these health situations, and help to inform students about the possible harmful link between experiencing pain and consuming dangerous drugs to cope with their pain. Moreover, given the finding of gender, age, and living situation on the observed relationship, special emphasis might be placed on younger students, on women, and on those who live away from home. In particular, prevention efforts and therapeutic strategies to reduce the excess use of toxic substances and to educate about the possible link between substance abuse and pain might be important to implement in college dormitories.

\section{Limitations}

There are three key limitations to this study. First, it is crosssectional. Second, this study used self-reported surveys. Third, the sample was one of convenience. Yet despite these limitations, the present analysis revealed there may be a critical problem among this cohort of college students regarding pain and excess drug use.

In this respect, although not discussed in detail in this paper, we feel the present data are reasonably representative of reality for the following reason, that is, we observed the lifetime prevalence of alcohol use among college students in this sample using the measures AUDIT and MAST was $74.2 \%$ and $77.7 \%$ respectively. In general, the rates for alcohol use as assessed in this study were very similar to prior reports on college student alcohol usage rates reported in the Monitoring the Future Studies in 2010 where $82 \%$ of college students had tried alcohol at least once in their lifetime and $71 \%$ reported they had been drunk.

As well, we recognize we did not measure which pain medications were taken and the quantity of these, but the rug Abuse Screening Test used only measures drug substance use (except alcohol and tobacco) but does not report what type of drugs has been used by the respondents. In spite of this however, DAST-10 has strong psychometric properties (Carey \& Chandra, 2003) and has been found to have good internal consistencies (reliability coefficient Chronbach's alpha $>0.85$ ) and acceptable temporal stabilities (reliability coefficient test-retest of $r>0.70$ ). The DAST- 10 has also been shown to possess good validity and reliability when the instrument was assessed with college students (non-clinical population). We recognize too, the present sample was one of conveni- 
Ferrer et al. Research Journal of Drug Abuse 2015,

ence, meaning that the criterion used to select samples was related to the variables of interest. In the future choosing participants in college at random might reduce any sampling bias. For example, one way of doing this could be obtaining a list of all the undergraduate students in this college and extract a sample randomly.

This may help to tease out why, although the prevalence of drug abuse in this sample was lower in females than males, there seemed to be a heightened risk among females for drug use when experiencing pain. This may also be a particular concern in the presence of pain among students with no affiliated religion or family, and more effective sampling might assist in identifying sub groups such as these who may be at greater use for drug use and abuse than others.

List of abbreviations

AUDIT: Alcohol Use Disorders Identification Test

DAST-10: Drug Abuse Screening Test

MAST: Michigan Alcohol Screening Test

SF-MPQ: Short-Form McGill Pain Questionnaire

VAS: Drug Abuse Screening Test

US: United States

Additional files

\section{Supplementary files}

\section{Competing interests}

The authors declare that they have no competing interests.

\section{Authors' contributions}

\begin{tabular}{|l|c|c|c|c|}
\hline Authors' contributions & EF & RM & EM & AHM \\
\hline Research concept and design & $\checkmark$ & $\checkmark$ & $\checkmark$ & -- \\
\hline Collection and/or assembly of data & $\checkmark$ & $\checkmark$ & -- & $\checkmark$ \\
\hline Data analysis and interpretation & $\checkmark$ & $\checkmark$ & $\checkmark$ & $\checkmark$ \\
\hline Writing the article & $\checkmark$ & $\checkmark$ & $\checkmark$ & $\checkmark$ \\
\hline Critical revision of the article & $\checkmark$ & $\checkmark$ & $\checkmark$ & $\checkmark$ \\
\hline Final approval of article & $\checkmark$ & $\checkmark$ & -- & -- \\
\hline Statistical analysis & $\checkmark$ & $\checkmark$ & -- & -- \\
\hline
\end{tabular}

Acknowledgement

The authors thank the college students for their willing participation.

\section{Publication history}

Editors: Alan H. B. Wu, University of California, USA.

Narayan G. Bhat, The University of Texas, USA.

Received: 27-Nov-2014 Final Revised: 28-Dec-2014

Accepted: 30-Dec-2014 Published: 09-Jan-2015

\section{References}

1. Kennedy C, Kassab O, Gilkey D, Linnel S and Morris D. Psychosocial factors and low back pain among college students. J Am Coll Health. 2008; 57:191-5. | Article | PubMed

2. McCabe SE, Cranford JA, Boyd CJ and Teter CJ. Motives, diversion and routes of administration associated with nonmedical use of prescription opioids. Addict Behav. 2007; 32:562-75. | Article | PubMed Abstract | PubMed Full Text

3. Manchikanti L, Cash KA, Damron KS, Manchukonda R, Pampati V and
McManus $C D$. Controlled substance abuse and illicit drug use in chronic pain patients: An evaluation of multiple variables. Pain Physician. 2006; 9:215-25. | Article | PubMed

4. Kanner RM and Foley KM. Patterns of narcotic drug use in a cancer pain clinic. Ann N Y Acad Sci. 1981; 362:161-72. | Article | PubMed

5. Topics in Brief: Prescription Drug Abuse. National Institute on Drug Abuse (NIDA). 2011. | Website

6. Kanner RM and Foley KM. Patterns of narcotic drug use in a cancer pain clinic. Ann N Y Acad Sci. 1981; 362:161-72. | Article | PubMed

7. O'Malley PM and Johnston LD. Epidemiology of alcohol and other drug use among American college students. J Stud Alcohol Suppl. 2002; 23-39. | Article | PubMed

8. Arria AM, Caldeira KM, O'Grady KE, Vincent KB, Fitzelle DB, Johnson EP and Wish ED. Drug exposure opportunities and use patterns among college students: results of a longitudinal prospective cohort study. Subst Abus. 2008; 29:19-38. | Article | PubMed Abstract | PubMed Full Text

9. Ross $\mathrm{V}$ and DeJong $\mathrm{W}$. Alcohol and other drug abuse among first-year college students. Higher Education Center for alcohol, drug abuse, and violence prevention. 2008.

10. McCabe SE, West BT and Wechsler H. Trends and college-level characteristics associated with the non-medical use of prescription drugs among US college students from 1993 to 2001. Addiction. 2007; 102:455-65. | Article | PubMed Abstract | PubMed Full Text

11. Warner M, Chen LH and Makuc DM. Increase in fatal poisonings involving opioid analgesics in the United States, 1999-2006. (NCHS) National Center for Health Statistics from CDC Centers for Disease Control and Prevention. 2009. I Article

12. National Survey on drug Use and Health (NSDUH). Drug Facts: Nationwide Trends, 2011. 2012.

13. Gfroerer JC. Substance use among older adults: Current prevalence and future expectations. National Institute on Drug Abuse. 2004. I Article

14. Matto $\mathrm{H}$, Miller KA and Spera $\mathrm{C}$. Examining the relative importance of social context referents in predicting intention to change substance abuse behavior using the EASE. Addict Behav. 2007; 32:1826-34. Article | PubMed

15. Arria AM, Caldeira KM, O'Grady KE, Vincent KB, Fitzelle DB, Johnson EP and Wish ED. Drug exposure opportunities and use patterns among college students: results of a longitudinal prospective cohort study. Subst Abus. 2008; 29:19-38. | Article | PubMed Abstract I PubMed Full Text

16. Kleber HD, Weiss RD, Anton RF, Jr., George TP, Greenfield SF, Kosten TR, O'Brien CP, Rounsaville BJ, Strain EC, Ziedonis DM and Hennessy G et al. Treatment of patients with substance use disorders, second edition. American Psychiatric Association. Am J Psychiatry. 2007; 164:5-123. | PubMed

17. Crippa JA, Derenusson GN, Chagas MH, Atakan Z, Martin-Santos R, Zuard AW and Hallak JE. Pharmacological interventions in the treatment of the acute effects of cannabis: a systematic review of literature. Harm Reduct J. 2012; 9:7. | Article | PubMed Abstract | PubMed Full Text

18. Shonkoff JP, Boyce WT and McEwen BS. Neuroscience, molecular biology, and the childhood roots of health disparities: building a new framework for health promotion and disease prevention. JAMA. 2009; 301:2252-9. | Article | PubMed

19. Levy A and Neri F. Macroeconomic aspects of substance abuse: Diffusion, productivity, and optimal control. Macroecon. Dynamics. 2004; 10:145-164. | Article

20. Weingarten TN, Martin DP and Bacon DR. The origins of the modern pain clinic at the Mayo Clinic. Bull Anesth Hist. 2011; 29:33, 36-9. | Article | PubMed

21. Scott DL, Wolfe F and Huizinga TW. Rheumatoid arthritis. Lancet. 2010; 376:1094-1108.

22. Gaskin DJ and Richard P. The economic costs of pain in the United States. J Pain. 2012; 13:715-24. | Article | PubMed

23. Skinner HA. The drug abuse screening test. Addict Behav. 1982; 7:36371. | Article | PubMed 
Ferrer et al. Research Journal of Drug Abuse 2015,

http://www.hoajonline.com/journals/pdf/2057-3111-2-1.pdf

24. Melzack R. The short-form McGill Pain Questionnaire. Pain. 1987; 30:191-7. | Article | PubMed

25. Gavin DR, Ross HE and Skinner HA. Diagnostic validity of the drug abuse screening test in the assessment of DSM-III drug disorders. Br J Addict. 1989; 84:301-7. | Article | PubMed

26. Huskisson EC. Measurement of pain. Lancet. 1974; 2:1127-31. | Article I PubMed

27. SPSS Inc. Released. PASW Statistics for Windows. Version 18.0. Chicago: SPSS Inc. 2009.

28. McCabe SE, Teter CJ and Boyd CJ. Medical use, illicit use, and diversion of abusable prescription drugs. J Am Coll Health. 2006; 54:269-78. Article | PubMed Abstract | PubMed Full Text

29. National Survey on Drug Use and Health (NSDUH). National Findings. 2003.

30. Ferrer E. Psychological mindedness (PM). A potential mediating variable in the substance abuse-pain cycle. Doctoral Dissertation. New York, Teachers College, Columbia University. 2012.

\section{Citation:}

Ferrer E, Marks R, Midlarsky E and Hutz-Midgett A. Substance abuse and pain in a cohort of college students. Res J Drug Abuse. 2015; 2:1.

http://dx.doi.org/10.7243/2057-3111-2-1 